\title{
SHOCK-WAVE STUDIES OF ICE UNDER UNIAXIAL STRAIN CONDITIONS
}

\author{
By Donald B. LaRson
}

(Lawrence Livermore National Laboratory, Livermore, California 94550, U.S.A.)

Abstract. Shock-wave studies of ice under uniaxial strain conditions . erated the flat-faced projectile used to impact the ice-containing targets. The ice samples were initially at ambient pressure and at temperatures of $-10 \pm 2^{\circ} \mathrm{C}$. Gages were implaced at different distances in the ice along the path of the shock wave to measure particle velocity time histories inside the ice samples. The recorded time histories of particle velocity show a precursor wave with an average wave velocity of $3.7 \mathrm{~km} / \mathrm{s}$ and an average particle velocity amplitude of $0.06 \mathrm{~km} / \mathrm{s}$. This wave is travelling at a wave velocity approximately $10 \%$ greater than longitudinal sound speed and is believed to originate because of the onset of melting of ice I.

The particle velocity data from these experiments were converted to stresses and volumes using Lagrangian gage analysis and the assumption of a simple non-steady wave. This conversion provides a complete compression cycle (which includes both loading and unloading paths) for comparison with static measurements. All experiments show the onset of melting at 0.15 to $0.2 \mathrm{GPa}$. Experiments with maximum stress states between 0.2 and 0.5 $\mathrm{GPa}$ yield results which suggest that a mixed phase of ice I and liquid water exists at these conditions. For maximum loading stresses between 0.6 and $1.7 \mathrm{GPa}$ the experimental results suggest that the final state is predominately ice VI. In these experiments the specific volume upon compression is changed from $1.09 \mathrm{~m}^{3} / \mathrm{Mg}$ to approximately $0.76 \mathrm{~m}^{3} / \mathrm{Mg}$, which represents compaction of approximately $30 \%$. The unloading paths determined from these experiments indicate that ice VI remains in a "frozen" or metastable state during most of the unloading process. This hysteresis in the compression cycle gives rise to a large "loss" of shock-wave energy to the transformation process. At stress levels above $2.2 \mathrm{GPa}$, ice VII should be the stable form for water according to static compression measurements. Experimental data at 2.4 and $3.6 \mathrm{GPa}$ suggest that ice VII may be formed but these results indicate a mixed phase of ice VI and ice VII rather than complete transformation to ice VII

Résumé. Études des ondes de choc de la glace sous des conditions de constrainte uniaxiales. On a conduit des études de l'onde de choc de la glace sous des conditions de contraintes uniaxiales avec des efforts allant jusqu'à 3,6 GPa. Un fusil à gaz accélérait un projectile à face plane pour produire un impact sur des cibles contenant de la glace. Les échantillons de glace étaient initialement à la pression ambiante et à des températures de $-10 \pm 2^{\circ} \mathrm{C}$. Des capteurs ont été implantés à différentes distances dans la glace le long du trajet de l'onde de choc pour mesurer la succession dans le temps des vitesses des particules à l'intérieur des échantillons de glace. Les enregistrements de cette succession temporelle des vitesses des particules mettent en évidence une onde en précurseur avec une vitesse moyenne de 3,7 $\mathrm{km} / \mathrm{s} \mathrm{et}$ une amplitude des variations de la vitesse de $0,06 \mathrm{~km} / \mathrm{s}$. Cette onde se déplace à une vitesse approximativement $10 \%$ plus grande que la vitesse longitudinale du son et on pense que c'est parce qu'il se produit une fusion de la glace $\mathrm{I}$.

Les données sur la vitesse des particules tirées de ces expériences ont été converties en efforts et en volumes en utilisant l'analyse du Lagrangien et l'hypothèse d'une onde simple instable. Cette conversion donne un cycle de compression complet (qui inclut à la fois la période de charge et de décharge) permettant une comparaison avec des mesures statiques. Toutes les expériences montrent une fusion de 0,15 à $0,2 \mathrm{GPa}$. Des expériences sous les efforts maximum, entre 0,2 et $0,5 \mathrm{GPa}$ donnent des résultats qui suggèrent

\section{IN TRODUCTION}

One of Nature's most valued components is the life-sustaining chemical water. This familiar yet unusual substance not only plays an important part in all biological processes but is important to geological processes as well. Water's geological role is most dramatically demonstrated in the Earth's cold regions or permafrost country. Although water and its large number of high-pressure phases (Bridgman, 1911, $1912,1914,1937)$ are intriguing from a pure science point of view, our main motivation for studying the behavior of ice under shock-wave loading stems from seismic monitoring application. Our interests are in qu'une phase mélangée de glace I et d'eau liquide existe dans ces conditions. Pour les charges les plus fortes entre 0,6 et 1,7 GPa les résultats expérimentaux font penser que l'état final est une prédominance de glace VI. Dans ces expériences le volume spécifique sous compression est chargé de $1,09 \mathrm{~m}^{3} / \mathrm{Mg}$ a approximativement $0,76 \mathrm{~m}^{3} / \mathrm{Mg}$, ce qui représente une compaction d'environ $30 \%$. L'itinéraire de décompression déterminé à partir de ces expériences indique que la glace VI reste dans un état "gelé" ou métastable durant la plus grande partie du processus de décompression. Cette hystérésis dans le cycle de la compression donne naissance à une forte "perte" de l'énergie de l'onde de choc pour le processus de transformation. A des niveaux d'efforts de $2,2 \mathrm{GPa}$, la glace VII devrait être la forme stable de l'eau, selon les mesures de compression statique. Des données expérimentales à 2,4 et 3,6 GPa suggèrent que de la glace VII peut se former mais les résultats montrent une phase mélangée de glaces VI et VII plutôt qu'une transformation complète en glace VII.

Zusammenfassung Untersuchung von Stosswellen in Eis unter einachsigen Spannungsbedingungen. Stosswellen in Eis unter einachsigen Spannungsbedingungen wurden bei Druckhöhen bis zu $3,6 \mathrm{GPa}$ untersucht. Eine Lichtgaskanone beschleunigte das stumpfe Geschoss, das zum Beschuss des eisgefüllten Zieles benutzt wurde. Die Eisproben standen anfänglich unter allseitigem Druck bei Temperaturen von $-10 \pm 2^{\circ} \mathrm{C}$. In verschiedenen Distanzen längs des Weges der Stosswelle wurden Messfühler ins Eis eingebracht, um den Verlauf der Teilchengeschwindigkeit in den Eisproben zu messen. Der registrierte Verlauf zeigt eine Vorläuferwelle mit einer mitt leren Wellengeschwindigkeit von $3,7 \mathrm{~km} / \mathrm{s}$ und einer mittlere Amplitude der Teilchengeschwindigkeit von $0,06 \mathrm{~km} / \mathrm{s}$. Diese Welle pflanzt sich mit einer um etwa $10 \%$ grösseren Geschwindigkeit als die Längsgeschwindigkeit des Schalles fort; ihr Ursprung dürfte auf den Beginn des Schmelzens von Eis I zurückgehen.

Die Werte der Teilchengeschwindigkeit bei diesen Versuchen wurden unter Verwendung der Lagrange-Analyse und unter der Annahme einer einfachen unstetigen Welle in Drucke und Volumina umgewandelt. Diese Umwandlung liefert einen vollständigen Kompressionszyklus (der sowoh Belastungs- wie Entlastungsbahnen enthält) zum Vergleich mit statischen Messungen. Alle Versuche zeigen den Beginn des Schmelzens bei 0,15 bis $0,2 \mathrm{GP}$. Versuche mit maximalen Druckzuständen zwischen 0,2 und 0,5 GPa liefern Ergebnisse, die das Vorhandensein einer Mischphase von Eis I und flüssigem Wasser unter diesen Bedingungen vermuten lassen. Bei maximalen Lastdrucken zwischen 0,6 und 1,7 GPa deuten die Ergebnisse auf einen Endzustand von im wesentlichen Eis VI hin. In diesen Versuchen wird das spezifische Volumen infolge Kompression von $1,09 \mathrm{~m}^{3} / \mathrm{Mg}$ auf etwa $0,76 \mathrm{~m}^{3} / \mathrm{Mg}$ verändert, was eine Verdichtung von etwa $30 \%$ darstellt. Die Entspannungswege, die aus diesen Versuchen bestimmt wurden, zeigen, dass Eis VI während des Grossteils des Entspannungsprozesses in einem "gefrorenen" oder metastabilen Zustand bleibt. Diese Hysterese im Kompressionszyklus verursacht einen starken "Verlust" von Energie der Stosswelle an den Transformationsprozess. Bei Druckhöhen über 2,2 GP sollte gemäss statischen Kompressionsmessungen die stabile Form für Wasser Eis VII sein. Versuchswerte bei 2,4 und 3,6 GPa lassen vermuten, dass Eis VII gebildet wird, aber diese Ergebnisse deuten eher auf eine Mischphase von Eis VI und Eis VII als auf eine vollständige Transformation zu Eis VII hin.

understanding the mechanisms of the processes occurring in ice and frozen soil that control the coupling of explosion energy and therefore the seismic signal amplitude that propagates through the Earth from frozen regions.

The objective of this paper is to report results from an experimental study of plane shock-wave loading of single and polycrystalline samples of ice which were initially at ambient pressure and a temperature of $-10 \pm 2^{\circ} \mathrm{C}$. The complexities associated with water are illustrated by the phase diagram shown in Figure 1 (Bridgman, 1942). Ice I is the familiar hexagonal form and ice VII is believed to be the ultimate close-packed high-pressure phase (Kamb and Davis, 


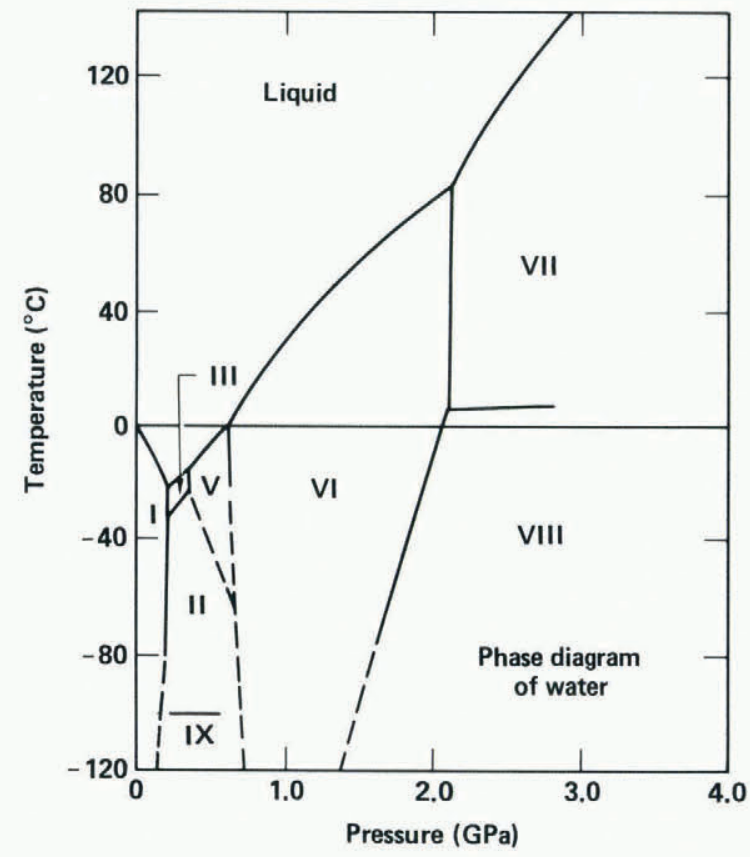

Fig. 1. Phase diagram of water.

1964). In an earlier paper (Larson and others, 1973), we presented data that suggested that ice I at $-10^{\circ} \mathrm{C}$ under shock loading is transformed to the liquid phase at stresses above approximately $0.2 \mathrm{GPa}$. Evidence was also given for the possible existence of a high-pressure solid phase. The research reported in this paper, with its more extensive study of ice I at $-10^{\circ} \mathrm{C}$ under dynamic loading, suggests the composition at most shock states is complex with the onset of melting and the formation of a mixed phase probable above $0.15-0.2 \mathrm{GPa}$. Moreover, these data suggest that at stress levels between 0.6 and $2.2 \mathrm{GPa}$, there is a transformation to ice VI which is nearly complete and is held in a metastable state during most of the unloading process.

\section{EXPERIMENTAL PROCEDURES AND RESULTS}

Shock-wave experiments were conducted using a light-gas gun to obtain loading of the ice samples under conditions of uniaxial strain. Flat-faced projectiles were accelerated with compressed gas before they impacted the target assembly shown in Figure 2 . The shock wave produced upon impact loads the sample; several microseconds later, a rarefaction from the free surface causes unloading, whereby the sample is relaxed to ambient stress conditions. The diagnostic velocity gages used were thin $\left(2.5 \times 10^{-2} \mathrm{~mm}\right)$ brass foils that were placed on the surface and also sandwiched between the plates of the target material. Because these gages were thin, they equilibrated to the surrounding material velocity within nanoseconds, thus following the motion of the sample material as both loading and unloading occurred. The foils were also constrained to move perpendicular to the field produced by a large external electromagnet. Under these conditions, the history of particle velocity with time, $U_{\mathrm{p}}(\tau)$ in kilometers per second, is proportional to the recorded electromotive force $E(\tau)$ in volts:

$$
U_{P}(\tau)=\frac{E(\tau)}{B L}
$$

where $B$ is the magnetic field strength in kilogauss and $L$ is the gage-element length in centimeters.
North pole

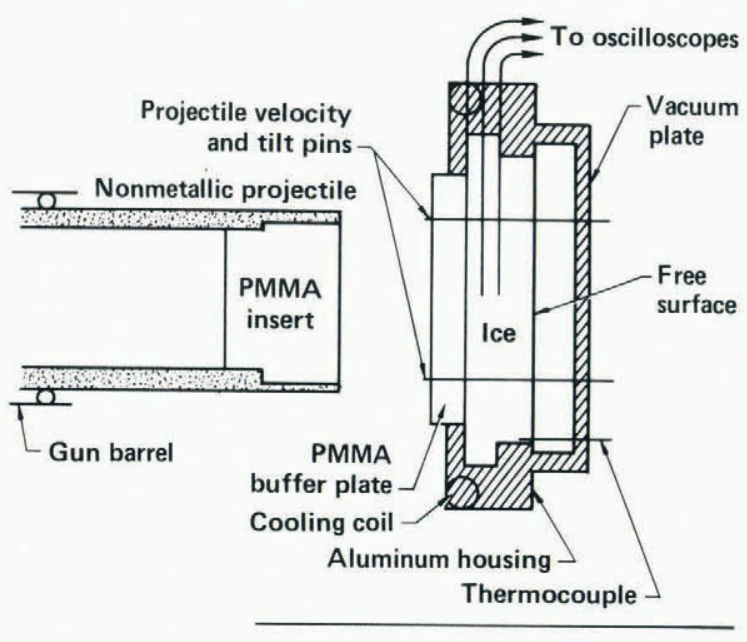

South pole

Fig. 2. Schematic of gas-gun experiment showing projectile, target assembly, and poles of external electomagnet.

Both $B$ and $L$ are measured and have a combined uncertainty of less than $1 \%$ for these experiments. During the fabrication of the experimental assemblies, the gages were placed on carefully machined surfaces (flat and parallel to approximately $0.008 \mathrm{~cm}$ ) of plates of ice. A thin film of water was used as a bonding agent to hold the plates together and fill any voids between plates.

The projectile insert and target buffer plate were made of polymethylmethacrylate (PMMA). The temperature was maintained at $-10 \pm 2^{\circ} \mathrm{C}$ by the controlled circulation of cold nitrogen vapors through a cooling coil mounted in an aluminum housing. The PMMA buffer plate and the aluminum vacuum plate were used to insulate the ice surfaces. A thermocouple was mounted in the ice to record sample temperature. In the enclosed assembly, a void between the rear plate of the ice and the rear of the target assembly provided the freesurface conditions necessary to unload the sample in uniaxial strain. The experimental assemblies were mounted mechanically between the magnet poles near the end of the barrel and in the vacuum chamber.

The data from each of the experiments were recorded as voltage-time histories of oscilloscope traces on Polaroid film. These records were digitized and then converted from voltage-time histories to particle-velocity-time histories using Equation (1). The conversion of these particle-velocity-time histories to equation-of-state data requires expressions relating particle-velocity history to the material properties of interest (i.e. stress and specific volume). These expressions can be derived by using the conservation equations for uniaxial flow. The equation for conservation of mass and linear momentum can be expressed as (Cowperthwaite and Williams, 1971).

$$
\begin{aligned}
& \left(\frac{\partial V}{\partial U_{\mathrm{p}}}\right)_{\mathrm{h}}=-\frac{V_{0}}{C_{U_{\mathrm{p}}}} \\
& \left(\frac{\partial \sigma}{\partial U_{\mathrm{p}}}\right)_{\mathrm{h}}=\rho_{0} C_{\sigma}
\end{aligned}
$$

where $\rho$ is the density (the subscript 0 refers to initial conditions), $V$ is specific volume, $\sigma$ is the 
axial stress, $h$ is the Lagrangian space coordinate, $t$ is the time, and

$$
C_{U_{p}}=\left(\frac{\partial h}{\partial t}\right)_{U_{p}}, \quad C_{\sigma}=\left(\frac{\partial h}{\partial t}\right)_{\sigma}
$$

In the analysis, it was assumed that the non-steady flow observed in ice samples was that of simple waves. In the case of non-steady simple waves, the phase velocities at constant stress and constant particle velocity, $C_{\sigma}$ and $C_{U}$ respectively, are equal but are

functions of particle velocities rather than constants. In this case, the digitized particle-velocity-time data from the experiments can be used to compare $C_{\sigma}$ and $C_{U_{p}}$, and the numerical integration of

Equations (2) and (3) can be used to obtain the relationship between stress and specific volume through the non-steady wave.

The ice used in these experiments was from two sources. The polycrystalline ice samples were made from blocks of commercial ice, while the single crystal ice was obtained from Dr K. Itagaki of the U.S. Army Cold Regions Research and Engineering Laboratory, Hanover, New Hampshire.

A typical series of particle-velocity-time histories for a single experiment is shown in Figure 3 .

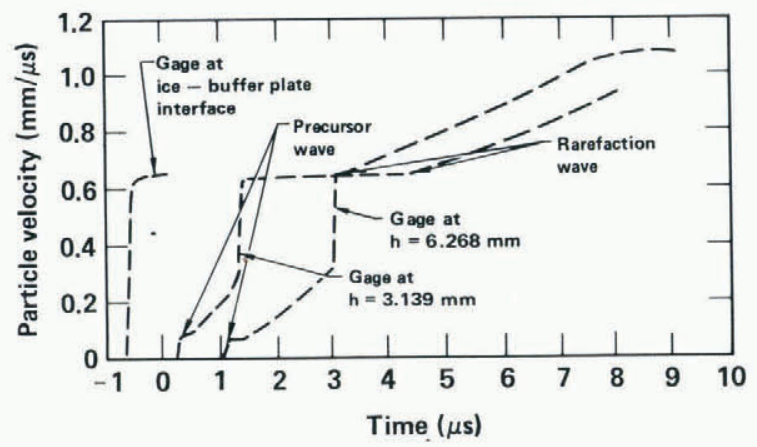

Fig. 3. Particle velocity time histories recorded at ice-buffer-plate interface and at depths of $3.139 \mathrm{~mm}$ and $6.268 \mathrm{~mm}$ in polycrystalline ice.

The first gage, located at the interface between the buffer plate and ice, shows the particle velocity imparted to the ice. The subsequent gages show the development of the wave profile, including the rarefaction from the free surface. The precursor wave which develops as the wave propagates in ice is attributed to the onset of melting. This wave propagates at a velocity of $3.63 \mathrm{~km} / \mathrm{s}$ which is about $10 \%$

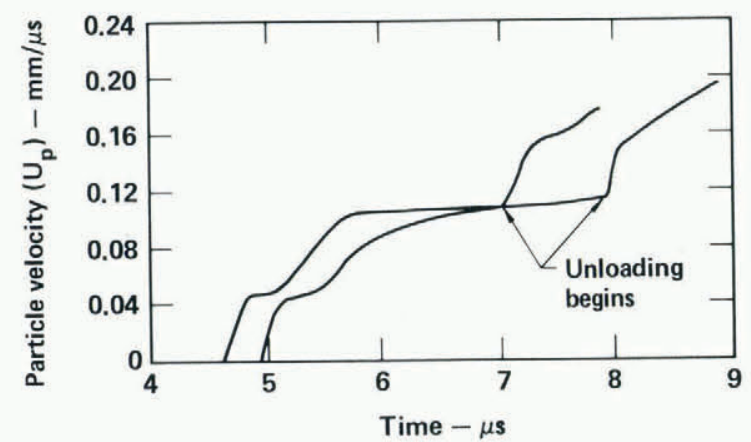

Fig. 4. Particle-velocity history of two embedded gages in single-crystal ice loaded uniaxially perpendicular to c-axis (arrows indicate arrival of rarefaction wave at gages). greater than the longitudinal sound speed. The dispersive-like feature of the wave following the precursor is associated with compaction of the material. This feature is followed by a steeply rising steady wave which takes the material to its final loading state. The last feature of the wave profile is the rarefaction wave with its ramp-like characteristics which result from unloading the ice beginning at the free surface.

Figure 4 shows particle-velocity-time histories for two gages embedded in single-crystal ice and loaded perpendicular to the $c$-axis along the $a$-axis or $<1010>$. In these records, the precursor moving at a velocity of $4.00 \mathrm{~km} / \mathrm{s}$ is clearly defined.

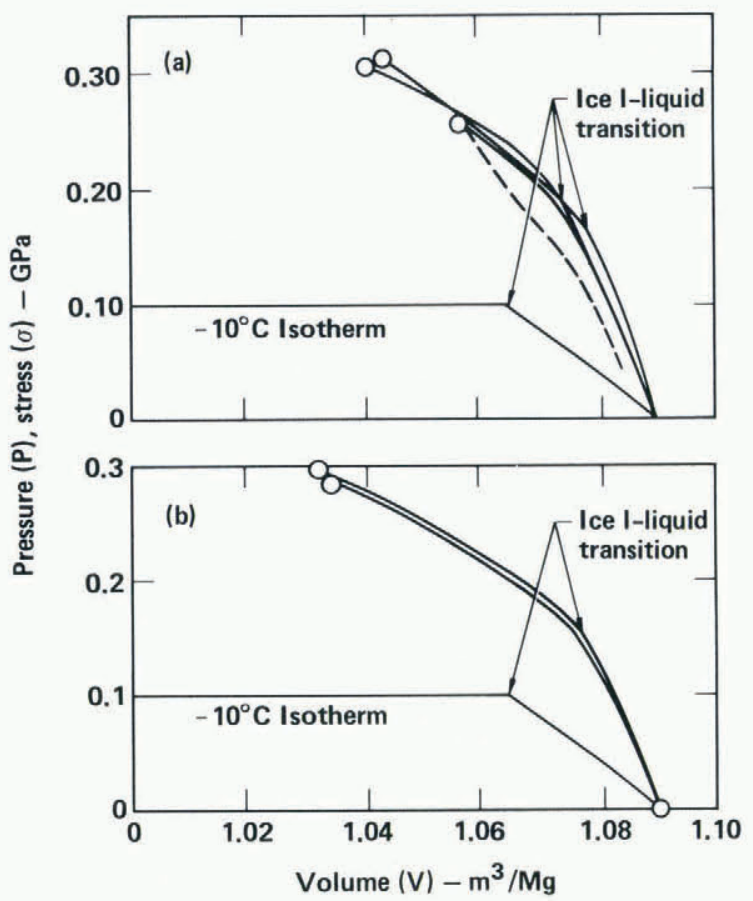

Fig. 5. Shock-wave compression data for single-crystal ice shocked (a) along $\langle 11 \overline{20}\rangle$ or $\langle 10 \overline{10}\rangle$ and (b) along $<0001>$ axis, starting at $-10^{\circ} \mathrm{C}$.

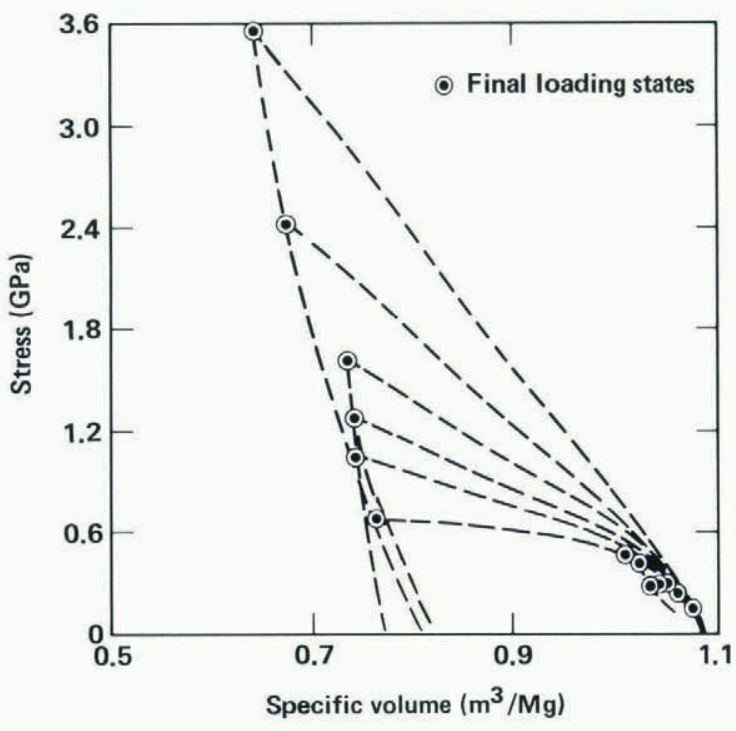

Fig. 6. Stress versus specific vol ume data for ice (dashed lines show miaxial loading and conloading paths followed in each experiment; solid line is average precursor path for all experiments). 
The precursor is followed by a ramp-like feature. However, the final loading stress is not large enough nor the compaction great enough to establish conditions where a second shock is obtained. The final feature on these records is the rarefaction or unloading wave.

In Table I and Figures 5 and 6 , the data from the various experiments are presented based upon analysis using Equations (2) and (3) and the assumption of simple non-steady waves. The data from single-crystal samples show little or no effect of crystal orientation on either the stress amplitude of the precursor or the specific volume at which it initiates. The implication is that differences in strength due to crystal orientation play little or no part in the development of the precursor at 0.16 to $0.19 \mathrm{GPa}$.

In Figure 6 , the data from all experiments both single crystal and polycrystalline are shown. The figure shows not only the development of the cusp around $0.2 \mathrm{GPa}$ but also the tremendous volume compaction that occurs at loading stresses above about $0.6 \mathrm{GPa}$. This compaction is followed by an abrupt stiffening of the material for stresses from about 0.6 to $3.6 \mathrm{GPa}$. The unloading paths measured at these larger stresses, i.e. greater than $0.6 \mathrm{GPa}$, indicate that the high-stress component produced upon loading is maintained in a metastable state through most of the unloading process.

\section{DISCUSSION OF RESULTS}

Some insight into the significance of the data shown in Figure 6 can be obtained through comparison with the $-10^{\circ} \mathrm{C}$ isotherm for water. Figure 7 shows this comparison and indicates various high-pressure phases that have been identified from static compression studies.

The cusp or "break" in the shock-wave compression curve at 0.15 to $0.2 \mathrm{GPa}$ has been interpreted (Larson and others, 1973; Larson, 1978) as arising from the onset of melting of ice I. An alternative interpretation would be the onset of dynamic yielding. However, as mentioned in the previous papers, the precursor which gives rise to the cusp has a wave velocity which is significantly ( $10 \%$ or more) greater than longitudinal sound speed. This is inconsistent with other observations of dynamic yielding where the precursor

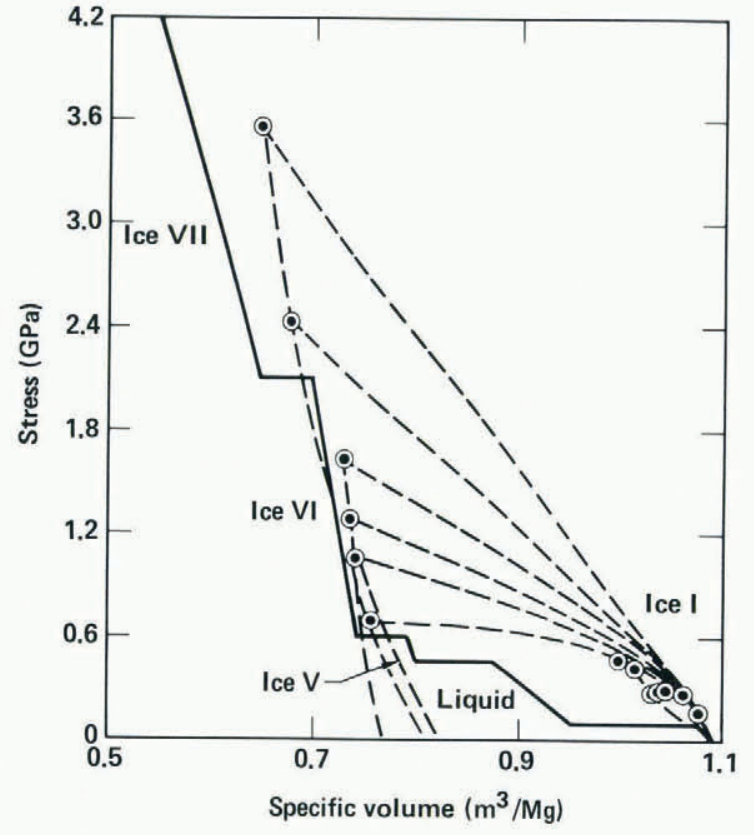

Fig. ?. Comparison of shock-wave data and $-10^{\circ}$ isotherm for ice.

velocity is equal to longitudinal sound speed. Moreover, the data on single crystals show that the precursor amplitude is unaffected by orientation. If the precursor were caused by dynamic yielding, such insensitivity would not be expected to occur because during static loading the strengths of single crystals differ by a factor of two or more depending upon orientation (Chamberlain, 1967). Furthermore, static values for strength at $-10^{\circ} \mathrm{C}$ are of the order of 10 $\mathrm{MPa}$ (Shōji and Higashi, 1978) and are not likely to increase to the order of $0.2 \mathrm{GPa}$ even at the strainrates of these experiments. However, recent data by Durham and others (in press) indicate that ice near $-10^{\circ} \mathrm{C}$ shows more than a doubling of strength as strain-rate increases from $3.5 \times 10^{-6} \mathrm{~s}^{-1}$ to $3.5 \times$

TABLE I. SHOCK-WAVE DATA FOR ICE

\begin{tabular}{|c|c|c|c|c|c|c|c|}
\hline $\begin{array}{l}\text { Sample } \\
\text { Single } \\
\text { crystal }\end{array}$ & $\begin{array}{c}\text { Shock } \\
\text { velocity } \\
\mathrm{km} / \mathrm{s}\end{array}$ & $\begin{array}{c}\text { Particle } \\
\text { velocity } \\
\mathrm{km} / \mathrm{s}\end{array}$ & $\begin{array}{c}\text { Stress } \\
\text { GPa }\end{array}$ & $\begin{array}{c}\text { Specific } \\
\text { volume } \\
m / \mathrm{Mg}\end{array}$ & $\begin{array}{c}\text { Particle } \\
\text { velocity } \\
\mathrm{km} / \mathrm{s}\end{array}$ & $\begin{array}{c}\text { Stress } \\
\text { GPa }\end{array}$ & $\begin{array}{l}\text { Specific } \\
\text { vol ime } \\
\mathrm{m} / \mathrm{Mg}\end{array}$ \\
\hline $\begin{array}{l}<11 \overline{2} 0> \\
<10 \overline{1} 0> \\
<11 \overline{2} 0>\end{array}$ & $\begin{array}{l}3.68 \\
4.0 \\
3.68\end{array}$ & $\begin{array}{l}0.051 \\
0.045 \\
0.056\end{array}$ & $\begin{array}{l}0.18 \\
0.16 \\
0.19\end{array}$ & $\begin{array}{l}1.075 \\
1.078 \\
1.074\end{array}$ & $\begin{array}{l}0.090 \\
0.105 \\
0.120\end{array}$ & $\begin{array}{l}0.26 \\
0.295 \\
0.305\end{array}$ & $\begin{array}{l}1.058 \\
1.049 \\
1.041\end{array}$ \\
\hline $\begin{array}{l}<0001> \\
<0001>\end{array}$ & $\begin{array}{l}3.46 \\
3.70\end{array}$ & $\begin{array}{l}0.049 \\
0.047\end{array}$ & $\begin{array}{l}0.16 \\
0.16\end{array}$ & $\begin{array}{l}1.075 \\
1.076\end{array}$ & $\begin{array}{l}0.125 \\
0.132\end{array}$ & $\begin{array}{l}0.285 \\
0.29\end{array}$ & $\begin{array}{l}1.035 \\
1.032\end{array}$ \\
\hline Polycrystal & $\begin{array}{l}3.60 \\
3.57 \\
3.84 \\
3.72 \\
3.63 \\
3.63 \\
3.59 \\
3.62\end{array}$ & $\begin{array}{l}0.045 \\
0.06 \\
0.05 \\
0.07 \\
0.07 \\
0.05 \\
0.07 \\
0.09\end{array}$ & $\begin{array}{l}0.15 \\
0.20 \\
0.18 \\
0.24 \\
0.23 \\
0.17 \\
0.23 \\
0.30\end{array}$ & $\begin{array}{l}1.076 \\
1.072 \\
1.071 \\
1.069 \\
1.069 \\
1.075 \\
1.069 \\
1.063\end{array}$ & $\begin{array}{l}0.165 \\
0.195 \\
0.41 \\
0.58 \\
0.65 \\
0.75 \\
1.00 \\
1.26\end{array}$ & $\begin{array}{l}0.42 \\
0.48 \\
0.69 \\
1.06 \\
1.27 \\
1.62 \\
2.43 \\
3.56\end{array}$ & $\begin{array}{l}1.020 \\
1.008 \\
0.760 \\
0.739 \\
0.738 \\
0.730 \\
0.675 \\
0.643\end{array}$ \\
\hline $\begin{array}{l}\text { Gaffney \& Ah } \\
\text { (pressed ice }\end{array}$ & $\begin{array}{l}\text { hrens } \\
\text { e) } 2.43\end{array}$ & - & - & 1.090 & 0.858 & 1.91 & 0.706 \\
\hline Anderson & $\begin{array}{l}3.23 \\
3.21\end{array}$ & - & - & - & $\begin{array}{l}1.25 \\
1.25\end{array}$ & $\begin{array}{l}3.75 \\
3.75\end{array}$ & $\begin{array}{l}0.669 \\
0.666\end{array}$ \\
\hline
\end{tabular}


$10^{-4} \mathrm{~s}^{-1}$. Whether this strain-rate effect can be extrapolated to strain-rates of $10^{+5} \mathrm{~s}^{-1}$ is conjecture; thus dynamic yielding remains as an alternative explanation for the precursor wave. However, even with these new data, our interpretation remains the same, $i$ :e. the precursor observed when shock loading ice I is attributed to the onset of melting of ice I. The onset of melting creates a mixed phase and absorbs energy from the system as latent heat of melting. This "loss" of energy results in a lowering of the average temperature of the system which may explain the higher threshold stress for transformation observed in these dynamic experiments.

The final loading states between 0.6 and $1.6 \mathrm{GPa}$ seem to suggest near complete transformation to ice VI. In a previous paper (Larson and others, 1973) we suggested that ice $V$ may be the final state for the point near $0.7 \mathrm{GPa}$ but re-analysis of those data and these new results suggest that ice $V I$ not ice $V$ is the final state. The small but consistent offset between the isotherm for ice VI and the final states deduced from the shock data is consistent with the expected higher temperatures that would occur along the Hugoniot. However, an alternative but less likely explanation would be incomplete transformation to ice VI. The unloading paths determined from these data show a strong hysteresis and imply that the ice VI state is maintained as a "frozen" or metastable state during most of the unloading process.

The comparison made in Figure 7 suggests that stresses above $2.2 \mathrm{GPa}$ should produce the onset of a transformation to ice VII. The shock-wave data at 2.4 and $3.6 \mathrm{GPa}$ are consistent with that expectation since they are displaced to the left of the lower-stress ice VI data but also suggest the possibility of a partial transformation or a mixed-phase region.

Figure 8 shows a possible path on the phase dia-

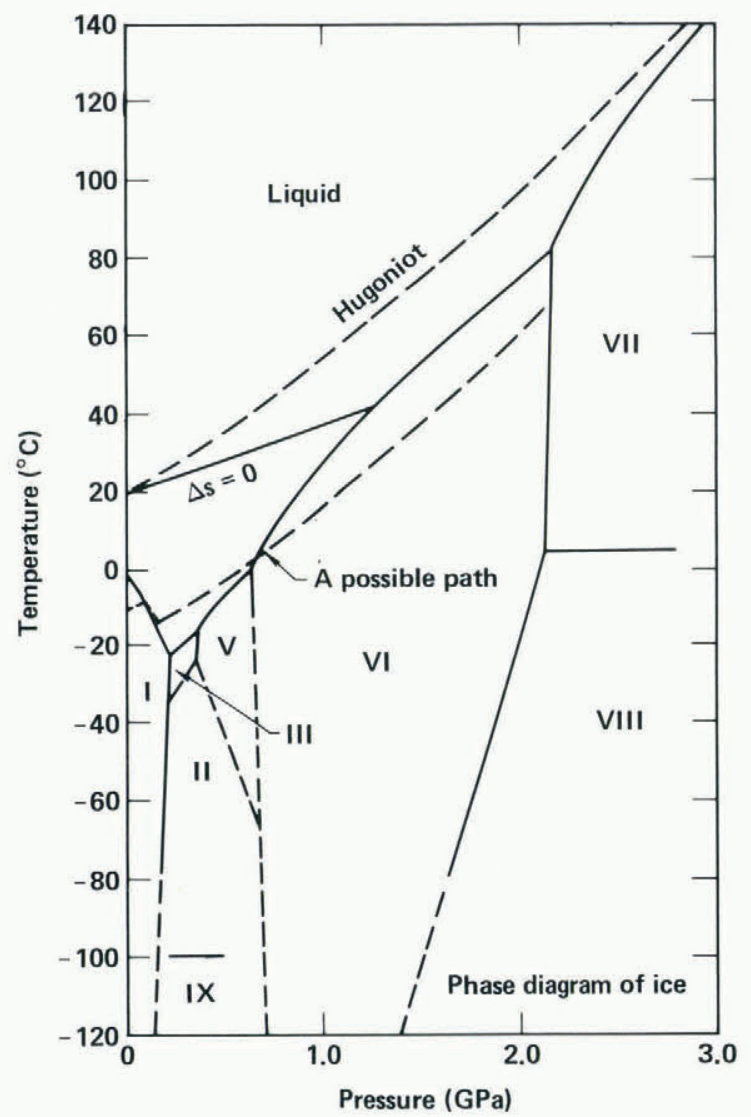

Fig. 8. Phase diagram for water with Hugoniot calculated for water at $20^{\circ} \mathrm{C}$ and possible path for shock-loading of ice I from $-10^{\circ} \mathrm{C}$. gram of water for shock loading of ice I from $-10^{\circ} \mathrm{C}$. Also shown is a Hugoniot for liquid water calculated by Anderson (Larson and Anderson, 1979). Transformation of liquid water into the high-pressure phase is unlikely unless the water is cooled to near $0^{\circ} \mathrm{C}$ and then only at stresses of the order of 1.5 to $2.0 \mathrm{GPa}$ would one expect to observe the formation of ice VI or ice VII. Kormer and others (1968) report the formation of ice VII but they could obtain this phase only by double shock-wave compression of liquid water.

\section{SUMMARY ANU CONCLUSIONS}

All of the experiments described in this study show the onset of melting at 0.15 to $0.2 \mathrm{GPa}$. Experiments with maximum stress states between 0.2 and 0.5 GPa yield results which suggest that a mixed phase of ice I and liquid water exists at these confining stresses. For maximum loading stresses between 0.6 and 1.7 $\mathrm{GPa}$ the experimental results suggest that the final state is predominantly ice VI. In these experiments the specific volume upon compression is changed from $1.09 \mathrm{~m}^{3} / \mathrm{Mg}$ to approximately $0.76 \mathrm{~m}^{3} / \mathrm{Mg}$, which represents compaction of approximately $30 \%$. The unloading paths determined from these experiments indicate that ice VI remains in a "frozen" or metastable state during most of the unloading process. This hysteresis in the compression cycle gives rise to a large "loss" of shock-wave energy to the transformation process. At stress levels above $2.2 \mathrm{GPa}$, ice VII should be the stable form for water according to static compression measurements. Experimental data at 2.4 and $3.6 \mathrm{GPa}$ suggest that ice VII may be formed but these results indicate a mixed phase of ice VI and ice VII rather than complete transformation to ice VII. Dynamic or shock-wave loading of ice form $-10^{\circ} \mathrm{C}$ produces high-pressure phases which in general remove a large fraction of the energy from the propagating shock wave. These processes begin at a stress of about $0.15 \mathrm{GPa}$ with the onset of melting and continue with transformations to ice VI and ice VII for stresses in excess of $0.6 \mathrm{GPa}$. Liquid water, on the other hand, is unlikely to transform along the Hugoniot unless cooled to near $0^{\circ} \mathrm{C}$ and then only at stresses of the order of 1.5 to $2.0 \mathrm{GPa}$ where transformation to ice VI or ice VII may occur.

\section{ACKNOWLEDGEMENTS}

I would like to acknowledge the invaluable support of J. Taylor, G. Hickman, G. Bearson, and E. Britton for their outstanding work in fabrication and assembly of the various experiments. This work was performed under the auspices of the U.S. Department of Energy by Lawrence Livermore National Laboratory under contract No. W-7405-Eng-48. I also appreciate the financial support of the Defense Advanced Research Projects Agency.

\section{RÉEE RENCES}

Bridgman, P.W. 1911. Water in the liquid and five solid forms, under pressure. Proceedings of the American Academy of Arts and Sciences, Vol. 47, No. 13, p. 441-558

Bridgman, P.W. 1912. Thermodynamic properties of 1 iquid water to $80^{\circ}$ and $12,000 \mathrm{kgm}$. Proceedings of the American Academy of Arts and Sciences, Vol. 48, No. 9, p. 309-62.

Bridgman, P.W. 1914. High pressure and five kinds of ice.Journal of the Franklin Institute, Vol. 177 , No. 3, p. 315-32.

Bridgman, P.W. 1937. The phase diagram of water to $45,000 \mathrm{~kg} / \mathrm{cm}^{2}$. Journal of Chemical Physics, Vol . 5, No. 12, p. 964-66.

Bridgman, P.W. 1942. Freezing parameters and compressions of twenty-one substances to $50,000 \mathrm{~kg} / \mathrm{cm}^{2}$. Proceedings of the American Academy of Arts and Sciences, Vol. 74, No. 12, p. 399-424. 
Chambepfałn, F. 1967. Some triaxial shear strength tests on frozen soil and ice.U.S. Cold Regions Research and Engineering Laboratory. Interim Technical Report [for Advanced Research Projects Agency ARPA Order 968].

Cowperthwaite, M., and Williams, R.F. 1971. Determination of constitutive relationships with multiple gauges in nondivergent waves. Journal of Applied Physics, Vol. 42, No. 1, p. 456-62.

Durham, W.B., and others. In press. Experimental deformation of polycrystalline $\mathrm{H}_{2} \mathrm{O}$ ice at high pressure and low temperature: preliminary results, by W.B. Durham, H.C. Heard, and S.H. Kirby. Joumal of Geophysical Research.

Kamb, W.B., and Davis, B.L. 1964. Ice VII, the densest form of ice. Proceedings of the National Academy of Sciences of the United States of America, Vol. 52, No. 6 , p. 1433-39.

Kormer, S.B., and others. 1968. Fazovoye prev-

rashcheniye vody $v$ led VII pri udarnom szhatii

[Phase transformation of water into ice VII by shock compression]. [By] S.B. Kormer, K.B. Yushko, G.V. Krishkevich. Zhurnal Eksperimentalnoy $i$

Teoreticheskoy Fiziki, Tom 54, Vyp. 6, p. 1640-45.

[English translation in Soviet Physics - JETP,

Vol. 27, No. 6, 1968, p. 879-81.]

Larson, D.B. 1978. Explosive energy coupling in ice and frozen soils. Proceedings of the third International Conference on Permafrost, July 10-13, 1978, Edmonton, Alberta, Canada, Vol . 1, p. 806-12.

Larson, D.B., and Anderson, G.D. 1979. Plane shock wave studies of porous geologic media. Journal of Geophysical Research, Vol. 84, No. B9, p. 4592-600. Larson, D.B., and others. 1973. Shock-wave studies of ice and two frozen soils, [by] D.B. Larson, G.D. Bearson, and J.R. Taylor. Permafrost. Second International Conference. 13-28 July 1973, Yakutsk, U.S.S.R. North American contribution, p. 318-25.

Shōji, H., and Higashi, A. 1978. A deformation mechanism map of ice. Journal of Glaciology, Vol. 21, No. 85, p. 419-27. 